НАУКОВИЙ ВІСНИК

Scientific messenger of Lviv National University of

$-1$

was

(1)

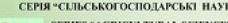

Том 22 № 92
Науковий вісник Дьвівського національного університету ветеринарної медищини та біотехнологій імені С.3. Гжицького. Серія: Сільськогосподарські науки

Scientific Messenger of Lviv National University of Veterinary Medicine and Biotechnologies. Series: Agricultural sciences

UDC 638.144:638.121.3

\title{
The influence of partial substitutes of protein feed of bees on the production of drone larvae homogenate
}

\author{
V. M. Nedashkivskyi
}

Bila Tserkva National Agrarian University, Bila Tserkva, Ukraine

Article info

Received 27.01.2020

Received in revised form 27.02.2020

Accepted 28.02.2020

Bila Tserkva National Agrarian University, Soborna pl. 8/1 Bila Tserkva, 09117, Ukraine. Tel: +38-097-153-30-53

E-mail:profkom1967@ukr.net
Nedashkivskyi, V. M. (2020). The influence of partial substitutes of protein feed of bees on the production of drone larvae homogenate. Scientific Messenger of Lviv National University of Veterinary Medicine and Biotechnologies. Series: Agricultural sciences, 22(92), 15-18. doi: $10.32718 /$ nvlvet-a9203

The biological value of the bee drone brood homogenate is showed. In recent times, the bee drone brood homogenate has become widely used among the population. In particular, the nutritional value the drone brood homogenate is determined by a high content of carbohydrates, fats, proteins, organic acids, vitamins, mineral compounds and other important chemical agent for the body. In the fresh state, the drone brood homogenate is cream-like, a slightly viscous substance of light yellow color with a pleasant smell of baked bread and a specific sweet taste. It has a high content of fat, protein and high biological value of elements compounds. Production the drone brood homogenate includes: preparation of bee colonies, rearing of drone brood, selection of drone brood and their processing. The drone brood homogenate contains about $73 \%$ of water, $13 \%$ of protein (21 free amino acids), $1 \%$ of fat (29 higher fatty acids), waterand fat-soluble vitamins, $131 \mathrm{mg} / \mathrm{kg}$ of carotene and also has an active acidity $(\mathrm{pH})$ at level of $6.5 \pm 0.29$. Chemical analysis of different age drone brood shows that the vast majority of identified substances are contained in the homogenate of seven-day drone brood which are the most suitable for homogenization in order to obtain the highest quality product. It is known that drone brood has the same properties as royal jelly. Both of these products contain almost the same amount of protein and reducing sugars per unit of dry weight. It was studied the effectiveness of using substitutes protein feeds (defatted soya flour with soy peptides and pollen) in bee feeding during the harvesting honey. It was found that feeding bee colonies with soy peptides are increased the production of drone brood homogenate by $79.6 \%$ in compared with using defatted soy flour.

Key words: drone brood homogenate, defatted soy flour, soy peptides, bee colonies.

\section{Вплив часткових замінників білкового корму бджіл на виробництво гомогенату трутневих личинок}

\author{
В. М. Недашківський
}

Білочерківський національний аграрний університет, м. Біла Церква, Украӥна

\footnotetext{
Показано біологічну иінність гомогенату виробленого із трутневих личинок бджолиних сімей. Останнім часом серед населення широкого використання набуває гомогенат трутневих личинок бджолиних сімей. Зокрема харчова цінність гомогенату трутневих личинок визначається високим вмістом вуглеводів, жсиів, білків, органічних кислот, вітамінів, мінеральних сполук та інших важливих для організму хімічних речовин. У свіжому стані гомогенат трутневих личинок являє собою вершковоподібну, злегка тягучу речовину світло-жовтого кольору із приємним запахом спеченого хліба і спечифічним солодкуватим смаком. Він має високий вміст жиру, білка та сполук елементів високої біологічної иінності. Виробництво гомогенату трутневих личинок включає: підготовку бджолиних сімей, вирощення трутневих личинок, відбір трутневих личинок та їх переробка. Гомогенат трутневих личинок містить близько 73 \% води, 13 \% білка (21 вільну амінокислоту), 1 \% жиру (29 вищих жирних кислот), водо- $і$ жиророзчинні вітаміни, 131 мг/кг каротину і має активну кислотність (pH) на рівні 6,5 \pm 0,29. Хімічний аналіз різновікових трутневих личинок свідчить, що переважна більщість ідентифікованих речовин міститься у гомогенаті семиденних трутневих личинок, які
} 
за віком є найпридатнішими для гомогенізачії з метою одержання продукту щчонайвищої якості. Відомо, щчо трутневий розплід має такі ж властивості, як і маточне молочко, обидва цүі продукти містять на одиницю сухої маси майже однакову кількість протеїну і відновлювальних иукрів. Вивчено ефективність підгодівлі бджолиних сімей білковими замінниками квіткового пилку, знежиреним соєвим борочном та соєвим пептоном в період підтримуючого медозбору. Виявлено, щзо за підгодівлі бджолиних сімей соєвим пептоном спостерігалося підвищення виробництва гомогенату трутневих личинок на 79,6 \% порівняно з використанням знежиреного соєвого борошна.

Ключові слова: гомогенат трутневих личинок, обезжирене соєве борошно, соєвий пептон, бджолині сім'ї.

\section{Вступ}

Наявні в гомогенаті трутневих личинок мінеральні речовини, зокрема натрій, калій, марганець, мідь, цинк, кальцій, магній, індукують ферменти детоксикації, імунного захисту, беруть участь у пластичних процесах, формуванні і побудові тканин, у водному обміні, підтримують осмотичний тиск крові й інших рідин організму, кислотно-лужну рівновагу. Макро- й мікроелементи, які є коферментами багатьох біохімічних реакцій, відіграють важливу роль у формуванні біологічної активності цього продукту. Трутневий розплід за мінеральним складом майже не відрізняється від маточного молочка, лише магнію, цинку і міді у трутневому розплоді було менше (Razanov et al., 2010; Iahich \& Losiev, 2020).

У гомогенаті трутневих личинок виявили також статеві гормони. Вміст тестостерону, прогестерону, пролактину й естрадіолу в трутневому розплоді порівняно з маточний молочком був значно вищим. Ймовірно, це зумовлено зростанням біологічної активності трутневого розплоду. Гормони, що входять до складу трутневого розплоду, не тільки діють на організм людини, а й сприяють відновленню органів ендокринної системи. Для збільшення ефективності дії до гомогенату додають пергу (Taranov, 1986).

Активність кислот фосфатази у гомогенаті трутневих личинок становить 413 мкг, тоді як у маточному молочку - 17 мкг на 100 мг продукту. Спостерігаються відмінності також і у кількості неорганічного фосфору (406 мкг у гомогенаті трутневих личинок проти 173,8 мкг у маточному молочці) на 100 г продукту. Його енергія необхідна для проходження різних процесів біосинтезу клітин за різноманітних захворювань, пов'язаних 3 порушенням обмінних та енергетичних процесів.

Підготовка бджолиних сімей до виробництва трутневих личинок, як сировини гомогенату, включає нарощування сили сім’ї. Схильні до роїння бджолині сім’ї активно вирощують трутневий розплід. Значно більше вирощують трутневого розплоду сім'ї із старими матками. Бджолина сім'я, що буде вирощувати трутневий розплід має бути забезпечена кормом: не менше 6 кг меду і 0,7 кг перги (Kosicyn, 2012).

Вирощування трутневого розплоду грунтується на природній здатності розмноження бджолиних сімей способом роїння, на період якого молоді матки мають бути забезпечені достатньою кількістю трутнів для спаровування. У зоні Лісостепу України репродукція трутнів триває впродовж трьох місяців (травеньлипень). Найінтенсивніше відкладання маткою гаплоїдних яєць і збільшення площі трутневих комірок на стільниках $з$ розплодом спостерігається із середини травня - до середини червня (Kosicyn, 2010).
Компактне розміщення вирощуваних трутневих личинок досягається шляхом застосування трутневої вощини як у рамках так і у спеціальних секціях, які вставляють у звичайну стандартну рамку $(435 \times 300$ мм) або у рамку багатокорпусного вулика. Після того як бджоли відбудують трутневий стільничок у вставленій секції, на нього пересаджують матку під ізолятором на одну добу для одержання засіву для вирощування личинок (Taranov, 1986).

Штучне вирощування трутневих личинок доповнює комплексне використання бджолиних сімей, не порушуючи звичайного ритму відтворного процесу в гнізді. За паралельного побічного збирання личинок для гомогенату можна одержати після фільтрування гомогенізованої біомаси понад 270 г продукту від однієї бджолиної сім’ї, без шкоди для іiі розвитку і продуктивності (Taranov, 1986).

Відомо, що інтенсивність вирощування розплоду i в тім числі трутневого залежить в певній мірі від наявності у бджолиних гніздах білкового корму. Однак, медоносна база лісостепу України в умовах інтенсивного землеробства не завжди може забезпечити постійне його надходження в бджолині гнізда, тому виникає необхідність в поповненні білкового корму його частковими замінниками (Vishchur et al., 2016; Kovalchuk et al., 2019; Vishchur et al., 2019).

У практиці бджільництва широкого розповсюдження набуває використання у годівлі бджіл соєвого борошна та продуктів його переробки як додаткового джерела білка (Fedoruk \& Romaniv, 2013).

Проте, вивчення впливу даних замінників на виробництво бджолами гомогенату трутневих личинок $є$ недостатнім.

Тому метою досліджень було вивчення впливу соєвого пептону на інтенсивність виробництва бджолиними сім'ями гомогенату трутневих личинок.

\section{Матеріал і методи досліджень}

У вивченні впливу замінників білкового корму бджіл на вироблення ними гомогенату трутневих личинок були задіяні бджолині сім’ї української породи бджіл. Бджолині сім'ї піддослідних груп були підібрані за принципом груп-аналогів.

Бджолиним сім'ям протягом десяти діб згодовували суміш, до складу якої входили цукрова пудра та білкові часткові замінники.

Згодовування даного корму проводили у вигляді тістоподібної маси по 250 грам на добу в період підтримуючого медозбору з 14.04 по 24.04. Відбір трутневих личинок із будівельних рамок проводили протягом третьої декади травня.

Бджолиним сім'ям контрольної групи згодовували корм до складу якого входило 95 \% цукрової пудри та 
$5 \%$ обезжиреного соєвого борошна, а бджолиним сім'ям дослідної групи 95 \% цукрової пудри та 5 \% соєвого пептону. Трутневі личинки одержували за рахунок будівельних рамок.

\section{Результати та їх обговорення}

Результати досліджень таблиці 1 показали, що підгодівля бджолиних сімей сойовим пептоном у складі цукрової пудри сприяло підвищенню вирощених бджолиними сім'ями розплоду на перший підрахунок 29,04 на $50 \%$, другий 11,05 на $36,1 \%$ і на третій 23.05 на 58,6 \% порівняно з їх аналогами яким згодовували обезжирене соєве борошно у складі цукрової пудри. Загалом бджолині сім'ї яким згодовували цукрову пудру і соєвий пептон виростили за обліковий період більше розплоду на 48,3 \% порівняно з їх аналогами, які підгодовували цукровою пудрою 3 обезжиреним соєвим борошном.

\section{Таблиця 1}

Розвиток бджолиних сімей

\begin{tabular}{|c|c|c|c|c|c|c|}
\hline $\begin{array}{c}\text { Піддослідні } \\
\text { бджолині сім’ї }\end{array}$ & $\begin{array}{c}\text { Нумерація } \\
\text { бджолиних сімей }\end{array}$ & Склад корму & 18.04 .17 & 29.04 .17 & 11.05 .17 & 23.05 .17 \\
\hline \multirow{10}{*}{ Контрольні } & 7 & \multirow{11}{*}{$\begin{array}{c}\text { цукрова пудра із } \\
\text { знежиреним соєвим } \\
\text { пептоном }\end{array}$} & 3150 & 4611 & 6107 & 7731 \\
\hline & 8 & & 3278 & 4029 & 6314 & 7237 \\
\hline & 1 & & 3457 & 4720 & 6277 & 7451 \\
\hline & 27 & & 3017 & 4012 & 6720 & 7025 \\
\hline & 31 & & 3554 & 4730 & 6134 & 7034 \\
\hline & 47 & & 3780 & 4150 & 6720 & 7820 \\
\hline & 52 & & 2989 & 4079 & 6840 & 8370 \\
\hline & 61 & & 3014 & 4291 & 5390 & 7460 \\
\hline & 12 & & 3151 & 4117 & 5920 & 6720 \\
\hline & 22 & & 3230 & 4072 & 6780 & 8350 \\
\hline Разом по групі & & & $3261 \pm 112$ & $4281 \pm 105$ & $6319 \pm 112$ & $7519 \pm 117$ \\
\hline \multirow{10}{*}{ Дослідні } & 34 & \multirow{11}{*}{$\begin{array}{l}\text { цукрова пудра із } \\
\text { соєвим пептоном }\end{array}$} & 3079 & 6370 & 8230 & 12129 \\
\hline & 47 & & 3078 & 6430 & 8150 & 12032 \\
\hline & 4 & & 3007 & 6970 & 7790 & 12720 \\
\hline & 7 & & 3456 & 6230 & 8310 & 11630 \\
\hline & 19 & & 3492 & 6450 & 8250 & 12450 \\
\hline & 57 & & 3005 & 6340 & 8724 & 11151 \\
\hline & 53 & & 3995 & 6560 & 9012 & 12970 \\
\hline & 23 & & 3117 & 6102 & 9019 & 10101 \\
\hline & 17 & & 3004 & 6092 & 9350 & 11750 \\
\hline & 28 & & 2921 & 6720 & 9170 & 12350 \\
\hline Разом по групі & & & $3215 \pm 110$ & $6426 \pm 114$ & $8600 \pm 118$ & $11928 \pm 119$ \\
\hline
\end{tabular}

\section{Таблиця 2}

Вплив часткових замінників білкового корму бджіл на виробництво гомогенату трутневих личинок

\begin{tabular}{|c|c|c|c|c|}
\hline $\begin{array}{c}\text { Піддослідні } \\
\text { бджолині сім’ї }\end{array}$ & $\begin{array}{c}\text { Номерація } \\
\text { бджолиних сімей }\end{array}$ & Склад корму & Період підгодівлі & $\begin{array}{l}\text { Одержано гомогенату } \\
\text { трутневих личинок, г }\end{array}$ \\
\hline \multirow{10}{*}{ Контрольні } & 7 & \multirow{11}{*}{$\begin{array}{c}\text { цукрова пудра із } \\
\text { знежиреним соєвим } \\
\text { борошном }\end{array}$} & \multirow{11}{*}{$14.04-24.04$} & 125 \\
\hline & 8 & & & 130 \\
\hline & 1 & & & 114 \\
\hline & 27 & & & 121 \\
\hline & 31 & & & 131 \\
\hline & 47 & & & 105 \\
\hline & 52 & & & 132 \\
\hline & 61 & & & 101 \\
\hline & 12 & & & 130 \\
\hline & 22 & & & 140 \\
\hline В середньому по групі & & & & $123 \pm 112$ \\
\hline \multirow{10}{*}{ Дослідні } & 34 & \multirow{11}{*}{$\begin{array}{l}\text { цукрова пудра із } \\
\text { соєвим пептоном }\end{array}$} & \multirow{11}{*}{$14.04-24.04$} & 234 \\
\hline & 47 & & & 208 \\
\hline & 4 & & & 242 \\
\hline & 7 & & & 221 \\
\hline & 19 & & & 212 \\
\hline & 57 & & & 232 \\
\hline & 53 & & & 218 \\
\hline & 23 & & & 251 \\
\hline & 17 & & & 180 \\
\hline & 23 & & & 217 \\
\hline В середньому по групі & & & & $221 \pm 110$ \\
\hline
\end{tabular}


Результати досліджень наведені у таблиці 2 показали, що у контрольній групі бджолиних сімей виробництво гомогенату трутневих личинок було в межах від 101 г до 140 г, тоді як у досліді від 208 г до 251 г. В середньому на одну бджолину сім'ю у контрольній групі вироблено 123 г гомогенату трутневих личинок а у дослідній 221 г.

\section{Висновки}

Підгодівля бджолиних сімей соєвим пептоном в складі цукрової пудри (5 \% соєвого пептону і 95 \% цукрової пудри) сприяло підвищенню вирощення розплоду на 48,7 \% та виробництву гомогенату трутневих личинок на 79,6 \% порівняно із обезжиреним соєвим борошном у складі цукрової пудри (5 \% обезжирене соєве борошно і 95 \% цукрової пудри).

\section{References}

Fedoruk, R. S., \& Romaniv, L. I. (2013). Reproduktyvna zdatnist bdzholynykh matok za umov pidhodivli bdzhil bo-roshnom $\mathrm{z}$ bobiv soi natyvnoho ta transhennoho sortiv. Biolohiia tvaryn, 15(3), 140-149. http://aminbiol.com.ua/index.php/ua/arkhiv/93-bt315-2013/265-2013-10-09-13-22-03 (in Ukrainian).

Iahich, H., \& Losiev, O. (2020). Analiz vmistu trutnevoho homohenatu zalezhno vid intensyvnosti rostu lychynok u stilnykakh riznoi heneratsii. Tvarynnytstvo Ukrainy, 1, 16-23. https://tvarynnyctvoua.at.ua/TY78_2019_site.pdf (in Ukrainian).
Kosicyn, N. V. (2010). Lesnoe zakonodatel'stvo v organizacii pchelovodstva. Pchelovodstvo: nauchno proizvodstvennyj zhurnal, 9, 46-49 (in Russian).

Kosicyn, N. V. (2012). Ocenka medonosnyh resursov po dannym gosudarstvennoj inventarizacii lesov. Pchelovodstvo: nauchno-proizvodstvennyj zhurnal, 10, 1820 (in Russian).

Kovalchuk, I., Dvylyuk, I., Lecyk, Y., Dvylyuk, I., \& Gutyj, B. (2019). Physiological relationship between content of certain microelements in the tissues of different anatomic sections of the organism of honey bees exposed to citrates of argentum and cuprum. Regulatory Mechanisms in Biosystems, 10(2), 177181. doi: 10.15421/021926.

Razanov, S. F., Bezpalyi, I. F., Bila, V. I., \& Donchenko, T. A. (2010). Tekhnolohiia vyrobnytstva produktsii bdzhilny-tstva. K.: Ahrarna osvita (in Ukrainian).

Taranov, G. F. (1986). Korma i kormlenie pchel. M.: Rossel'hozizdat (in Russian).

Vishchur, V. Y. Saranchuk, I. I., \& Gutyj, B. V. (2016). Fatty acid content of honeycombs depending on the level of technogenic loading on the environment. Visnyk of Dnipropetrovsk University. Biology, ecology, 24(1), 182-187. doi: 10.15421/011622.

Vishchur, V. Y., Gutyj, B. V., Nischemenko, N. P., Kushnir, I. M., Salata, V. Z., Tarasenko, L. O., Khimych, M. S., Kushnir, V. I., Kalyn, B. M., Magrelo, N. V., Boiko, P. K., Kolotnytskyy, V. A., Velesyk, T., Pundyak, T. O., \& Gubash, O. P. (2019). Effect of industry on the content of fatty acids in the tissues of the honey-bee head. Ukrainian Journal of Ecology, 9(3), 174-179. doi: 10.15421/2019_727. 